\title{
Lack of transmission of TT virus through immunoglobulins
}

\author{
Chiara Azzari, Massimo Resti, Maria Moriondo, Eleonora Gambineri, Maria Elisabetta Rossi, \\ Elio Novembre, and Alberto Vierucci
}

BACKGROUND: A high prevalence of TT virus (TTV) infection has been found in patients who received blood or blood components. Viral DNA was demonstrated in commercial preparations of FVIII and F IX, but very few data have been reported on immunoglobulins. The risk of TTV infection associated with intramuscular or IV immunoglobulin administration is unclear.

STUDY DESIGN AND METHODS: The prevalence of TTV infection in a group of patients undergoing lifelong therapy because of congenital immunodeficiency has been evaluated in a long term follow-up (median, 6 years). Seventeen patients with congenital immunodeficiency receiving monthly administration of IVIG were included in the study. TTV DNA was repeatedly evaluated by PCR in serum samples from each patient during the follow-up. Research of antibodies against TTV was not applicable, as the patients studied were unable to produce antibodies. The presence of TTV was also evaluated in 15 IVIG lots. RESULTS: The total amount of immunoglobulin administered was $18,773 \mathrm{~g}$. TTV infection was not found in any patients included in the study. None of the 15 immunoglobulin preparations analyzed was found positive for TTV DNA. CONCLUSION: Despite the high prevalence of TTV in blood donors, commercial immunoglobulins are safe and unable to transmit TTV.

ABBREVIATIONS: TTV = TT virus; IMIG = intramuscular immunoglobulin.

From the Pediatric Clinic III, University of Florence, and the A. Meyer Pediatric Hospital, Florence, Italy.

Address reprint requests to: Chiara Azzari, MD, Department of Pediatrics, Via Luca Giordano 13, I-50132 Firenze, Italy; email: c.azzari@ao-meyer.toscana.it.

Received for publication January 25, 2001; revision received June 11, 2001, and accepted July 18, 2001.

TRANSFUSION 2001;41:1505-1508.
A novel DNA virus, TT virus (TTV), has been implicated as a cause of posttransfusion hepatitis. ${ }^{1}$ The existence of several genotypes of the virus has been shown by studies, ${ }^{2,3}$ and, as with HCV, multiple variants may be found in the same patients. ${ }^{4,5} \mathrm{In}$ all the variants, the noncoding region of the viral genome is the most highly conserved. On the other hand, the sequence of the coding region, which is more variable, is usually used to divide the virus into different genotypes. At present, more than 15 genotypes have been described. ${ }^{6}$ Correlation between genotypes and the geographic source of the virus has not been shown. ${ }^{4} \mathrm{~A}$ high prevalence of TTV infection has been found in patients who received blood or blood components. ${ }^{7,8}$ Viral DNA was demonstrated in commercial preparations of FVIII and F IX. ${ }^{8}$ Other parenterally transmitted viruses such as $\mathrm{HCV}$, have been shown in intramuscular immunoglobulin (IMIG) or IVIG preparations, ${ }^{9,10}$ and sporadic outbreaks of HCV infections occurred before 1994. ${ }^{11}$

Recently, the presence of TTV DNA was confirmed in IMIG batches, ${ }^{12}$ but very few data have been reported on IVIG. Little is known about the risk of TTV infection in association with IMIG or IVIG administration. The aim of the present study was to investigate the prevalence of TTV infection in a group of patients undergoing lifelong therapy with monthly administration of IVIG because of congenital immunodeficiency.

\section{MATERIALS AND METHODS}

\section{Patients}

Seventeen patients (12 males, 5 females) with congenital immunodeficiency were included in the study. All the patients received monthly doses of IVIG (Endobulin, Baxter, Pisa, Italy; IgVENA, Sclavo-Chiron, Siena, Italy; or Venogamma, Alfa Wassermann, Pescara, Italy). Two patients (men, 29 and 30 years old) had received IMIG before IVIG became available. The median age of the patients at the time of the study was 50 months (range, 17 months-30 years). All the patients had been followed since they first received immunoglobulins. The median follow-up on the patients studied was 6 years (range, 12 months-25 years). In Table 1, the immunologic disease diagnosed, the age and sex of the patients, and the duration 
of IVIG therapy are reported. For each patient, at least two serum samples were analyzed during the follow-up. All of the sera analyzed had been stored at $-80^{\circ} \mathrm{C}$ and not thawed before testing for TTV DNA.

\section{Detection of TTV sequences}

Total DNA was extracted from $200 \mu \mathrm{L}$ of serum by use of a blood kit (QIAamp, QIAGEN Ltd, Crawley, UK) and resuspended in $50 \mu \mathrm{L}$ of elution buffer. Total DNA was also extracted from $200 \mu \mathrm{L}$ of 15 samples of IVIG ( 2 archived and 3 current preparations for each of Endobulin, IgVENA, and Venogamma). Samples of IMIG were not available for testing.

TTV DNA was amplified by semi-nested PCR with TTVspecific primers derived from a conserved region of the published sequences. ${ }^{13,14}$ Specifically, TTV DNA was amplified by

\begin{tabular}{|c|c|c|c|c|}
\hline \multicolumn{5}{|c|}{$\begin{array}{l}\text { TABLE 1. Diagnosis of immunologic disease, age, sex, and duration } \\
\text { of IVIG therapy in } 17 \text { patients with congenital immunodeficiency who } \\
\text { received monthly IVIG doses }\end{array}$} \\
\hline Patient & Diagnosis & $\begin{array}{l}\text { Age } \\
\text { months) }\end{array}$ & Sex & $\begin{array}{l}\text { Duration of IVIG } \\
\text { therapy (months) }\end{array}$ \\
\hline 1 & X-linked agammaglobulinemia & 360 & $M$ & $300 *$ \\
\hline 2 & X-linked agammaglobulinemia & 344 & M & 288 * \\
\hline 3 & $\mathrm{X}$-linked agammaglobulinemia & 145 & $\mathrm{M}$ & 139 \\
\hline 4 & $\mathrm{X}$-linked agammaglobulinemia & 50 & M & 44 \\
\hline 5 & X-linked agammaglobulinemia & 18 & M & 11 \\
\hline 6 & Severe combined immunodeficiency & 74 & M & 68 \\
\hline 7 & Autosomal agammaglobulinemia & 142 & $\mathrm{~F}$ & 138 \\
\hline 8 & Autosomal agammaglobulinemia & 127 & $\mathrm{~F}$ & 111 \\
\hline 9 & Common variable immunodeficiency & 204 & $\mathrm{~F}$ & 61 \\
\hline 10 & Common variable immunodeficiency & 170 & M & 121 \\
\hline 11 & Transient hypogammaglobulinemia of infancy & 30 & $\mathrm{~F}$ & 26 \\
\hline 12 & Transient hypogammaglobulinemia of infancy & 25 & M & 21 \\
\hline 13 & Transient hypogammaglobulinemia of infancy & 24 & M & 18 \\
\hline 14 & Transient hypogammaglobulinemia of infancy & 24 & M & 20 \\
\hline 15 & Transient hypogammaglobulinemia of infancy & 19 & M & 15 \\
\hline 16 & Transient hypogammaglobulinemia of infancy & 18 & $\mathrm{~F}$ & 12 \\
\hline 17 & Transient hypogammaglobulinemia of infancy & 17 & $M$ & 13 \\
\hline \multicolumn{5}{|c|}{$\begin{array}{l}\text { Administration of IVIG was started in 1984; before that date, the patients received } \\
280 \mathrm{~g} \text { (Patient \#1) and } 310 \mathrm{~g} \text { (Patient \#2) of IMIG. }\end{array}$} \\
\hline
\end{tabular}

PCR in a thermal cycler (2400, Perkin-Elmer, Emeryville, CA) by the following protocol: 35 cycles at $94^{\circ} \mathrm{C}$ for 30 seconds, at $58^{\circ} \mathrm{C}$ for 30 seconds, and at $72^{\circ} \mathrm{C}$ for 45 seconds and 1 cycle at $72^{\circ} \mathrm{C}$ for 7 minutes. The reaction conditions were $20 \mathrm{pmol}$ of each primer (Primer A: sense, 5' -ACA GAC AGA GGA GAA GGC AAC ATG-3', position 1900-1923 from ORF-1; Primer B: antisense, 5'-CTG GCA TTT TAC CAT TTC CAA AGT-3', position 2185-2161) and 2.5 U of Taq polymerase (Polymed, Milan, Italy) in a $50-\mu \mathrm{L}$ reaction volume. Five $\mu \mathrm{L}$ of the products of amplification was amplified in a second round of PCR by use of a semi-nested primer set (primer C: sense, 5'-GGC AAC ATG TTA TGG ATA GAC TGG-3', position 1915-1938; antisense, the same Primer B) under the same conditions described above. The length of the amplicons obtained was $270 \mathrm{bp}$. Multiple positive and negative controls were included in each PCR assay. PCR products were analyzed in a 2-percent agarose gel electrophoresis with ethidium bromide staining. ${ }^{7}$ For IVIG samples and for pooled sera that were negative for TTV, $10 \mu \mathrm{L}$ of a positive serum sample was added and TTV testing was repeated to exclude the presence of possible Taq inhibitors. Research on antibodies against TTV was not applicable, as the patients studied were unable to produce immunoglobulins.

\section{RESULTS}

For each patient, the number of immunoglobulin administrations, the amount of immunoglobulin received (in grams), and the number of TTV PCRs performed are reported in Table 2 . The total number of parenteral immunoglobulin ad-

\begin{tabular}{|c|c|c|c|c|}
\hline Patient & $\begin{array}{c}\text { Number of } \\
\text { immunoglobulin } \\
\text { administrations }\end{array}$ & $\begin{array}{l}\text { Immunoglobulins } \\
\text { received }(\mathrm{g})\end{array}$ & $\begin{array}{l}\text { Number of } \\
\text { TTV PCRs } \\
\text { performed }\end{array}$ & $\begin{array}{c}\text { Age of } \\
\text { patients at } \\
\text { TTV PCR (months) }\end{array}$ \\
\hline 1 & 302 & 6060 & 8 & $144,168,212,237,298,331,348,357$ \\
\hline 2 & 283 & 5100 & 5 & $91,163,220,275,343$ \\
\hline 3 & 145 & 1210 & 7 & $23,46,88,106,117,132,141$ \\
\hline 4 & 42 & 289 & 4 & $12,22,29,48$ \\
\hline 5 & 14 & 43 & 2 & 10,16 \\
\hline 6 & 74 & 481 & 4 & $13,24,36,70$ \\
\hline 7 & 148 & 1040 & 7 & $37,48,61,85,99,106,138$ \\
\hline 8 & 123 & 1081 & 7 & $24,38,45,68,93,104,120$ \\
\hline 9 & 65 & 1500 & 4 & $145,168,181,201$ \\
\hline 10 & 129 & 1502 & 7 & $50,63,77,98,123,138,163$ \\
\hline 11 & 26 & 98 & 3 & $6,10,28$ \\
\hline 12 & 21 & 74 & 3 & $7,13,23$ \\
\hline 13 & 18 & 77 & 2 & 9,15 \\
\hline 14 & 18 & 72 & 3 & 8,20 \\
\hline 15 & 14 & 50 & 2 & 6,17 \\
\hline 16 & 14 & 43 & 2 & 7,18 \\
\hline 17 & 9 & 53 & 2 & 5,16 \\
\hline
\end{tabular}


ministrations in the 17 patients was 1445 and the total amount of immunoglobulin administered was $18,773 \mathrm{~g}$. The median number of TTV PCRs performed in each patient was 4 (range, 2-8).

TTV DNA was not found in any of the serum samples analyzed. None of the 15 immunoglobulin preparations analyzed was found positive for TTV DNA. All IVIG samples and pooled sera to which positive serum was added were found positive for TTV DNA.

\section{DISCUSSION}

The present results show that TTV is not transmitted through IVIG: more than 18,000 g of immunoglobulin was administered to the patients, and no case of TTV infection was recorded. These results could be due to the absence of TTV in plasma pools. However, with the same primers, the prevalence of TTV in a normal population of blood donors in Italy is 22 percent. $^{7}$ Therefore, given the high prevalence of TTV infection in blood donors and plasma pools ${ }^{7,12}$ and the huge number of transfusions received by the patients, the absence of infection is more likely due to the removal or inactivation of TTV by the manufacturing process. This is confirmed by studies conducted by other authors. Pisani et al., ${ }^{12}$ with a set of primers derived from a conserved region of TTV, could detect TTV DNA in 70 percent of four plasma pools derived from blood donors from different countries, whereas IVIG was consistently negative with the same primer set. The same authors demonstrated that the large majority of FVIII concentrates and a high number of IMIG batches are TTV positive. The results obtained in the present research confirm that, unlike FVIII concentrates, IVIG preparations are free of TTV sequences. ${ }^{14}$

At present, most IVIG products released in the world are subjected to a virus-inactivation step using S/D treatment or pasteurization. ${ }^{9,10,15-17}$ We cannot exclude that other methods of virus inactivation may be less effective in eliminating TTV or other blood-borne viruses. Six patients were already receiving IVIG substitute therapy before 1994, and the present results suggest that TTV was probably inactivated also by the procedures performed before that time. Moreover, as has previously been described for other nonenveloped DNA viruses, ${ }^{17}$ TTV virus may be removed during a purification step before S/D treatment or pasteurization.

Recently, it has been suggested that the use of different primer sets or longer times of extension or annealing during PCR may increase the sensitivity of the method, but the same authors also suggested the need for development of international standards. ${ }^{18}$

The immunologic disorders of the patients studied, who were unable to produce immunoglobulins, precluded the evaluation of TTV antibodies. Therefore, the present data cannot exclude, in older patients, transient TTV viremia. However, this possibility seems extremely unlikely, because, as has been repeatedly shown, TTV DNA persists through a follow-up of years in infected patients. ${ }^{7,19,20}$ In particular, in multiply transfused patients, a chronic infection may be observed in more than 80 percent of the cases, ${ }^{7,20}$ and TTV DNA has been shown to persist in serum samples taken up to 6 years apart in individual patients. ${ }^{19}$ Moreover, virus clearance is usually decreased in immunodeficient patients; therefore, the hypothesis of transient viremia and resolution of TTV infection is even more unlikely in these patients than in an immunocompetent host.

In conclusion, the present findings suggest that the fractionation process and stringent procedures to inactivate viruses make commercial IVIG safe and unable to transmit TTV.

\section{ACKNOWLEDGMENTS}

The authors sincerely thank Sergio Nanni for expert technical assistance.

\section{REFERENCES}

1. Nishizawa T, Okamoto H, Konishi K, et al. A novel DNA virus (TTV) associated with elevated transaminase levels in posttransfusion hepatitis of unknown etiology. Biochem Biophys Res Commun 1997;241:92-7.

2. Okamoto H, Kato N, Iizuka H, et al. Distinct genotypes of a nonenveloped DNA virus associated with posttransfusion non-A to G hepatitis (TT virus) in plasma and peripheral blood mononuclear cells. J Med Virol 1999;57:252-8.

3. Takayama S, Yamazaki S, Matsuo S, Sugii S. Multiple infection of TT virus (TTV) with different genotypes in Japanese hemophiliacs. Biochem Biophys Res Commun 1999;256:208-11.

4. Mushahwar IK, Erker JC, Muerhoff AS, et al. Molecular and biophysical characterization of TT virus: evidence for a new virus family infecting humans. Proc Natl Acad Sci U S A 1999;96:3177-82.

5. Ball JK, Curran R, Berridge S, et al. TT virus sequence heterogeneity in vivo: evidence for co-infection with multiple genetic types. J Gen Virol 1999;80:1759-68.

6. Okamoto H, Takahashi M, Nishizawa T, et al. Marked genomic heterogeneity and frequent mixed infection of TT virus demonstrated by PCR with primers from coding and noncoding regions. Virology 1999;259:428-36.

7. Prati D, Lin YH, De Mattei C, et al. A prospective study on TT virus infection in transfusion-dependent patients with thalassemia. Blood 1999;93:1502-5.

8. Simmonds P, Davidson F, Lycett C, et al. Detection of a novel DNA virus in blood donors and blood products. Lancet 1998;352:191-5.

9. Piazza M. Immunoglobulin transmits hepatitis C. True or false? Hepatology 1999;29:299-300.

10. Chapel HM. Safety and availability of immunoglobulin replacement therapy in relation to potentially 
transmissable agents. IUIS Committee on Primary Immunodeficiency Disease International Union of Immunological Societies. Clin Exp Immunol 1999;118:29-34.

11. Outbreak of hepatitis $C$ associated with intravenous immunoglobulin administration-United States, October 1993-June 1994. MMWR Morb Mortal Wkly Rep 1994;4331:505-9.

12. Pisani G, Cristiano K, Wirz M, et al. Prevalence of TT virus in plasma pools and blood products. Br J Haematol 1999;106:431-5.

13. Okamoto H, Nishizawa T, Kato N, et al. Molecular cloning and characterization of a novel DNA virus (TTV) associated with posttransfusion hepatitis of unknown etiology. Hepatol Res 1998;10:1-16.

14. Wang JT, Lee CZ, Kao JH, et al. Incidence and clinical presentation of posttransfusion TT virus infection in prospectively followed transfusion recipients: emphasis on its relevance to hepatitis. Transfusion 2000;40:596-601.
15. Cristiano K, Wirz M, Gentili G. Do intravenous immunoglobulin products manufactured from plasma collected in Italy place immunocompromised patients at risk of contracting human herpesvirus 8? Transfusion 2000;40:258-9.

16. Chandra S, Cavanaugh JE, Lin CM, et al. Virus reduction in the preparation of intravenous immunoglobulin: in vitro experiments. Transfusion 1999;39:249-57.

17. Cristiano K, Pisani G, Wirz M, Gentili G. Hepatitis G virus in intramuscular and intravenous immunoglobulin products manufactured in Europe. Transfusion 1999;39:428.

18. Biagini P, Gallian P, Touinssi M, et al. High prevalence of TT virus infection in French blood donors revealed by the use of three PCR systems. Transfusion 2000;40:590-5.

19. Irving $\mathrm{WL}$, Ball JK, Berridge $\mathrm{S}$, et al. TT virus infection in patients with hepatitis C: frequency, persistence, and sequence heterogeneity. J Infect Dis 1999;180:27-34.

20. Lefrere JJ, Roudot-Thoraval F, Lefrere F, et al. Natural history of the TT virus infection through follow-up of TTV DNA-positive multiple-transfused patients. Blood 2000;95:347-51. 